\title{
Electrical Wire Device
}

National Cancer Institute

\section{Source}

National Cancer Institute. Electrical Wire Device. NCI Thesaurus. Code C50336.

A wire designed for electrical transmission of signal or power. 